\title{
The Time and Order of Appearance of Ossification Centers in the Hamster before Birth
}

\author{
Eisaku KANAZAWA* and Koshi MOCHIZUKI** \\ *Department of Anatomy, School of Medicine, Kitasato University, Sagamihara, \\ Kanagawa and **Department of Veterinary Anatomy, Faculty of Agriculture, \\ Tokyo University, Bunkyo-ku, Tokyo
}

(Accepted for publication: Feb. 26, 1974)

\begin{abstract}
The time and order of appearance of the ossification centers of the skull, the axial skeleton, the appendicular skeleton, and the pectoral and pelvic girdles were studied in fetuses of the golden hamster. They were cleared with $\mathrm{KOH}$ and stained with alizarin red S by Dawson's method. The results obtained were as follows.

1. The first appearance of an ossification center in all the skeletons is in the clavicle at 11 days and 15 hours post coitus. 2. In the axial skeletons, the first ossification center appears in the cervical vertebral arches at 12 days and 15 hours. The vertebral bodies ossify at 13 days and 12 hours in the thoracic bodies somewhat later than the respective vertebral arches. 3. The anterior appendages begin to ossify a few hours earlier than the posterior ones. 4. The first ossification center in the skull appears in the mandible at 12 days. Before the time of birth all the skull bones except for the ethmoid begin to ossify. 5. The ossification of newborn hamsters seems immature when compared to those of the rat and the mouse in which more ossification centers are present at birth than in the hamster, especially in the manus and pes.-Exp. Animals, 23 (3), 113-122, 1974.
\end{abstract}

\section{Introduction}

The golden hamster, characterized by a shorter gestation period and more rapid development in the prenatal period than most of other laboratory mammalian animals, was studied as to osteogenesis by Beatty et al. [2] for the first time in 1950. In that study, they recorded the time of appearance of ossification centers and concluded that the appearance of ossification centers in the hamster was "explosive". Arsdel et al. [1] reported the ossification in the middle and internal ear of this animal. Friant $[6,7]$ histologically investigated the ossification of Meckel's cartilage. Recently, Rajtova [10] described the development of the chondrocranium in detail by the method of serial sectioning. As for the development and the growth of bones in the postnatal life, a few studies were reported by Beyerlein et al. [3] and Schumacher et al. [12]. These studies give an outline of the development of bones in the hamster, but as to the time and order of appearance of ossification centers, the results were not conclusive.

In the present study, in order to get a standard of the bone growth in the hamster, the time and order of appearance of ossification centers in the fetuses were investigated in detail.

\section{Materials and Methods}

The fetuses of the golden hamster (Mesocricetus auratus var cream) used in this study were ob- 
Table 1. Number of specimens used in this study.

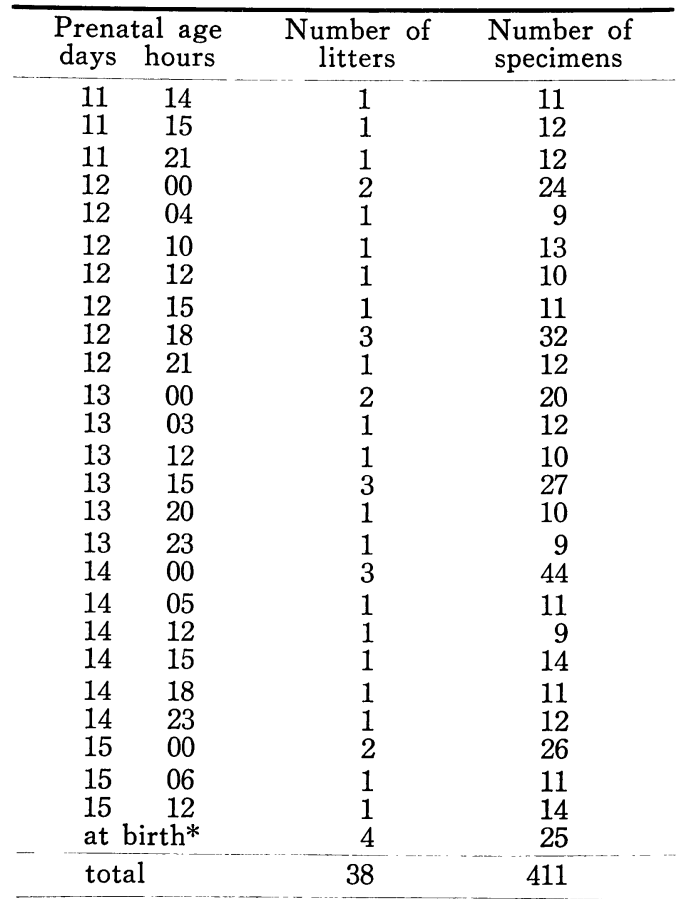

* The time of first birth of the four litters: 15 days 14 hours, one litter, 15 days 15 hours, two litters and 15 days 16 hours, one litters.

Table 2. The time of appearance of ossification centers in the vertebrae.

\begin{tabular}{|c|c|c|c|c|c|c|}
\hline \multirow{2}{*}{ 1. Arches } & \multicolumn{2}{|c|}{$\begin{array}{c}\text { earliest } \\
\text { days: hours }\end{array}$} & \multicolumn{2}{|c|}{$\begin{array}{c}\text { mean } \\
\text { days : hours }\end{array}$} & \multicolumn{2}{|c|}{$\begin{array}{c}\text { latest } \\
\text { days: hours }\end{array}$} \\
\hline & 12 & 12 & 12 & 15 & 12 & 21 \\
\hline T.V. 1-2 & 12 & 12 & 12 & 15 & 12 & 21 \\
\hline T.V. 3-5 & 12 & 15 & 12 & 21 & 13 & 12 \\
\hline T.V. 6-9 & 12 & 18 & 13 & 00 & 13 & 12 \\
\hline T.V. $10-13$ & 12 & 15 & 12 & 21 & 13 & 12 \\
\hline L.V. $1-4$ & 12 & 15 & 12 & 21 & 13 & 12 \\
\hline L.V. 5-6 & 12 & 18 & 13 & 00 & 13 & 12 \\
\hline S.V. $1-2$ & 13 & 00 & 13 & 15 & 13 & 20 \\
\hline S.V. 3 & 14 & 00 & 14 & 05 & 14 & 12 \\
\hline Ca.V. & 14 & 23 & 15 & 06 & & birth \\
\hline \multicolumn{7}{|l|}{ 2. Bodies } \\
\hline C.V. $1-5$ & 15 & 00 & 15 & 06 & & birth \\
\hline C.V. $6-7$ & 14 & 00 & 14 & 12 & 14 & 18 \\
\hline T.V. 1-2 & 13 & 20 & 14 & 05 & 14 & 12 \\
\hline T.V. 3 & 13 & 15 & 13 & 20 & 14 & 05 \\
\hline T.V. 4-5 & 13 & 12 & 13 & 15 & 14 & 00 \\
\hline T.V. 6-9 & 13 & 12 & 13 & 12 & 13 & 20 \\
\hline T.V. $10-13$ & 13 & 12 & 13 & 15 & 14 & 00 \\
\hline L.V. $1-3$ & 13 & 12 & 13 & 15 & 14 & 00 \\
\hline L.V. 4-6 & 13 & 15 & 13 & 20 & 14 & 00 \\
\hline S.V. $1-3$ & 13 & 20 & 14 & 05 & 14 & 15 \\
\hline
\end{tabular}

mean: the time when an ossification center was found in more than half individuals of a litter.

earliest: the time when an ossification center was found in at least one individual of a litter.

latest: the time when an ossification center was found in all individuals of a litter.

Explanation of abbreviations: C.V., cervical vertebrae; T.V., thoracic vertebrae; L.V., lumbar vertebrae; S.V., sacral vertebrae; Ca.V., caudal vertebrae. tained from our closed colony descended from the colony of NBS*. The hamster exhibits regular estrus cycles with ovulation every four days and the onset of psychic estrus in females commences between 7 p.m. and 11 p.m. in our colony. Virgin females and the males were placed in mating cages at 8 p.m. every day and observed for copulation. The time of copulation was recorded after each mating which continued 30 minutes to 1 hour. Ovulation is considered to occur between 12 midnight and 1 a.m. [11]. The ovum is fertilized 6 to 12 hours after the ovulation, actual time of the fertilization being difficult to determine. Therefore, the days and hours of gestation were counted from the end of each mating. Four hundred and eleven fetuses from 11 days of gestation until birth (table 1) were cleared with $\mathrm{KOH}$ and stained with alizarin red S (alizarin sodium monosulphonate) by Dawson's method [5]. Twenty newborns from birth until 30 days of age were also studied for the purpose of reference. * Nippon Institute for Biological Science

\section{Observations}

1. The Axial Skeleton (table 2,3). The golden hamster has 42 vertebrae. The number of the cervical, thoracic, lumbar, sacral and caudal vertebrae are $7,13,6,3$, and 13 respectively.

As shown in fig. 1, ossification ceters appear at first as two extremely small dots of staining in the cervical arches and the first two thoracic arches at 12 days and 15 hours. From the tenth arch to the fourth lumbar, they appear at 12 days and 21 hours, and from the sixth to the ninth thoracic arches and from the fifth to the sixth lumbar arches, they appear at 13 days. The first and second sacral arches ossify at 13 days and 15 hours, and the third sacral arch begins to ossify at 14 days and 15 hours. By 15 days and 6 hours the arches of the caudal vertebrae from the first to the third begin to ossify.

The ossification centers of the vertebral bodies, which have not appeared when the respective vertebral arches begin to ossify, are observed for the first time from the sixth to the ninth thoracic vertebral bodies at 13 days and 12 hours. The ossification of ver- 
tebral bodies extends from that time forward to cervical region and backwards to the caudal.
The first five cervical vertebral bodies ossify at 15 days and 6 hours, the last among the

Fig. 1. Average ossification in the vertebral arches and bodies.

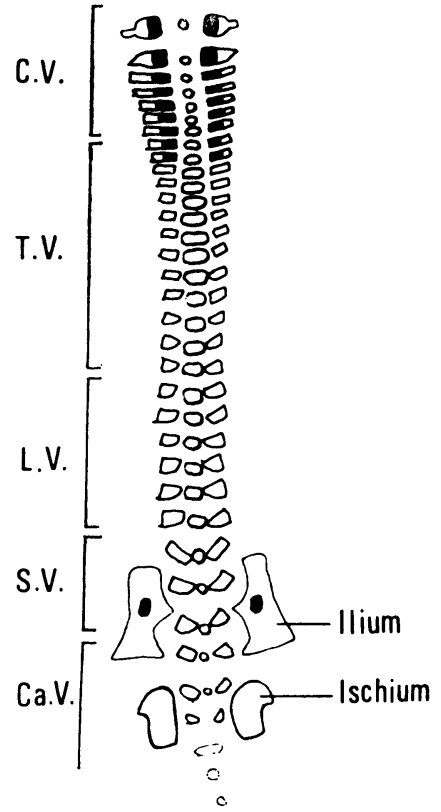

12 days 15 hours

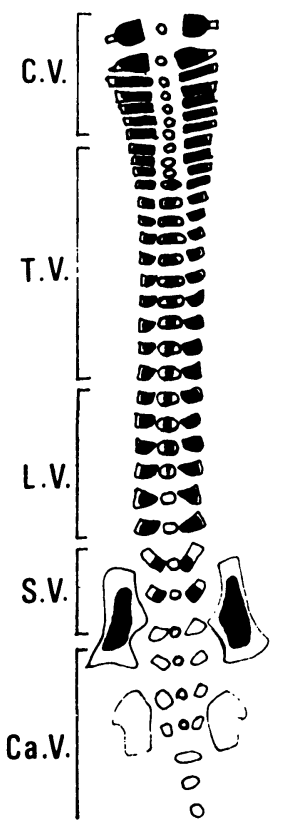

13 days 15 hours

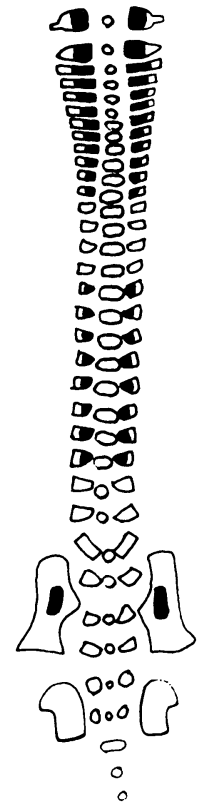

12 days 21 hours

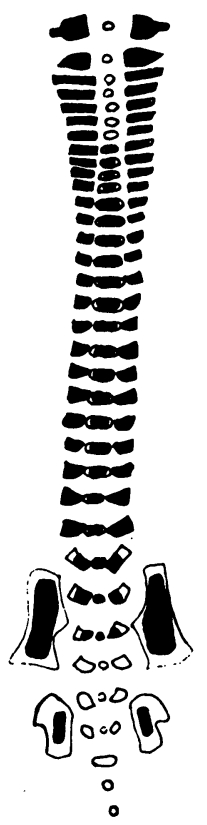

14 days 5 hours

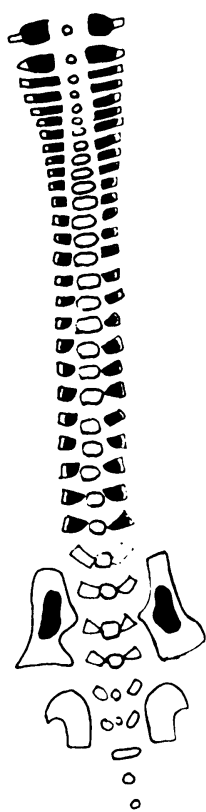

13 days 0 hours

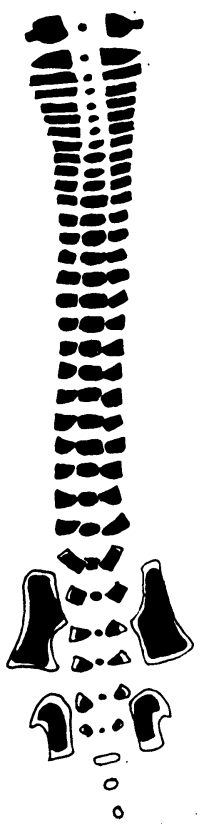

15 days 6 hours

The lines indicate ossified area at birth and the dark portions inside the lines indicate the ossification at the prenatal age described in the figure. Explanation of the abbreviations: C.V., cervical vertebrae; T.V., thoracic vertebrae; L.V., lumbar vertebrae; S.V., sacral vertebrae; Ca.V., caudal vertebrae. 
Table 3. The time of appearance of ossification centers in the sternum and the ribs.

\begin{tabular}{lllllllll}
\hline & \multicolumn{3}{c}{$\begin{array}{c}\text { earliest } \\
\text { days : hours }\end{array}$} & \multicolumn{2}{c}{$\begin{array}{c}\text { mean } \\
\text { days : hours }\end{array}$} & \multicolumn{2}{c}{$\begin{array}{c}\text { latest } \\
\text { days : hours }\end{array}$} \\
\hline Sternebra & 1 & 14 & 05 & 14 & 12 & 14 & 15 \\
$2-4$ & 14 & 23 & 15 & 06 & 15 & 12 \\
& 5 & & & \multicolumn{2}{c}{$\begin{array}{l}\text { after birth } \\
\end{array}$} \\
& 6 & 14 & 15 & 14 & 23 & 15 & 06 \\
\hline Ribs & 1 & 12 & 21 & 13 & 00 & 13 & 12 \\
& $2-13$ & 12 & 12 & 12 & 21 & 13 & 03 \\
\hline
\end{tabular}

Refer to Table 2. for explanations.

vertebral bodies.

The ossification centers of all the ribs except for the first one appear at 12 days and 21 hours. The first rib begins to ossify at 13 days. The first sternebra ossifies at 14 days and 12 hours. The sixth sternebra ossifies at 14 days and 23 hours, and the ossification centers of the second, third and fourth sternebrae at 15 days 6 hours. Only the fifth sternebra was recognized to be ossified after birth.

2. The Pectoral and Pelvic Girdles (table 4, fig. 2). The ossification center of the clavicle was observed at 11 days and 15 hours of gestation and this was the first ossification among all the bones. At birth, the ossified shaft of the clavicle is about $4 \mathrm{~mm}$ long, whereas its epiphysis does not show any sign of ossification.

The ossification in the scapula occurs at 12 days and 10 hours. Two centers appear at first at the edges of the bone separately, which immediately fuse with each other to form a single wide plate. At birth, the plate is $3.5 \mathrm{~mm}$ in width.

The ossification of the ilium appears as a ring at 12 days and 15 hours in the diaphysis. It develops to $2 \mathrm{~mm}$ long at birth. At 14 days and 5 hours, the ossification centers of the pubis and the ischium appear. At birth, the pubis is $0.8 \mathrm{~mm}$ in length, and the ischium is twice the length of the pubis. The foramen obturatum is not formed at this time.

3. The Appendages (table 4, fig. 2). The
Table 4. The time of appearance of ossification centers in the bones of girdles and appendages.

\begin{tabular}{|c|c|c|c|c|c|c|}
\hline \multirow[b]{2}{*}{ Clavicle } & \multicolumn{2}{|c|}{$\begin{array}{c}\text { earliest } \\
\text { days: hours }\end{array}$} & \multicolumn{2}{|c|}{$\begin{array}{c}\text { mean } \\
\text { days: hours }\end{array}$} & \multicolumn{2}{|c|}{$\begin{array}{c}\text { latest } \\
\text { days : hours }\end{array}$} \\
\hline & 11 & 15 & 11 & 15 & 11 & 21 \\
\hline Scapula & 12 & 10 & 12 & 10 & 12 & 12 \\
\hline Ilium & 12 & 12 & 12 & 15 & 12 & 18 \\
\hline Ischium & 13 & 23 & 14 & 05 & 14 & 05 \\
\hline Pubis & 13 & 23 & 14 & 05 & 14 & 05 \\
\hline \multicolumn{7}{|c|}{ Anterior appendages } \\
\hline Humerus & 12 & 00 & 12 & 10 & 12 & 12 \\
\hline Ulna & 12 & 10 & 12 & 12 & 12 & 12 \\
\hline Radius & 12 & 10 & 12 & 12 & 12 & 12 \\
\hline \multicolumn{7}{|l|}{ Metacarpal } \\
\hline $2-4$ & 13 & 23 & 14 & 05 & 14 & 12 \\
\hline 5 & 15 & 12 & \multicolumn{2}{|c|}{ at birth } & & \\
\hline \multicolumn{3}{|c|}{ Distal phalanges } & 13 & 23 & 14 & 05 \\
\hline \multicolumn{7}{|c|}{ Posterior appendages } \\
\hline Femur & 12 & 12 & 12 & 15 & 12 & 18 \\
\hline Tibia & 12 & 12 & 12 & 15 & 12 & 18 \\
\hline Fibula & 12 & 12 & 12 & 15 & 12 & 18 \\
\hline $\begin{array}{c}\text { Metatarsus } \\
2-4 \\
5\end{array}$ & $\begin{array}{l}14 \\
15\end{array}$ & $\begin{array}{l}15 \\
12\end{array}$ & \multicolumn{2}{|c|}{$\begin{array}{l}14 \quad 23 \\
\text { at birth }\end{array}$} & 15 & 00 \\
\hline \multicolumn{3}{|c|}{ 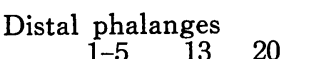 } & 13 & 23 & 14 & 05 \\
\hline
\end{tabular}

Refer to Table 2. for explanations.

Table 5. The time of appearance of ossification centers in the skull.

\begin{tabular}{lcccccc}
\hline & \multicolumn{2}{c}{$\begin{array}{c}\text { earliest } \\
\text { days: hours }\end{array}$} & \multicolumn{2}{c}{$\begin{array}{c}\text { mean } \\
\text { days : hours }\end{array}$} & \multicolumn{2}{c}{ latest } \\
days: hours
\end{tabular}

Refer to Table 2. for explanations. 
ossification of the humerus occurs at 12 days and 10 hours as a slender ring. At birth, the humerus is about $4 \mathrm{~mm}$ long. It was observed that the ossification of the humerus precedes that of the ulna and the radius. At 12 days and 12 hours, the cylindrical ossification centers appear in the radius and the ulna for the first time. The center of the radius is smaller than that of the ulna. At birth, the ulna is $3.8 \mathrm{~mm}$ and the radius is about $3.0 \mathrm{~mm}$ in length.

The ossification in the long bones of the hind limbs seem to start at the same time. At 12 days and 15 hours, the ossification cen-

Fig. 2. Average ossification in the girdles and the appendages.

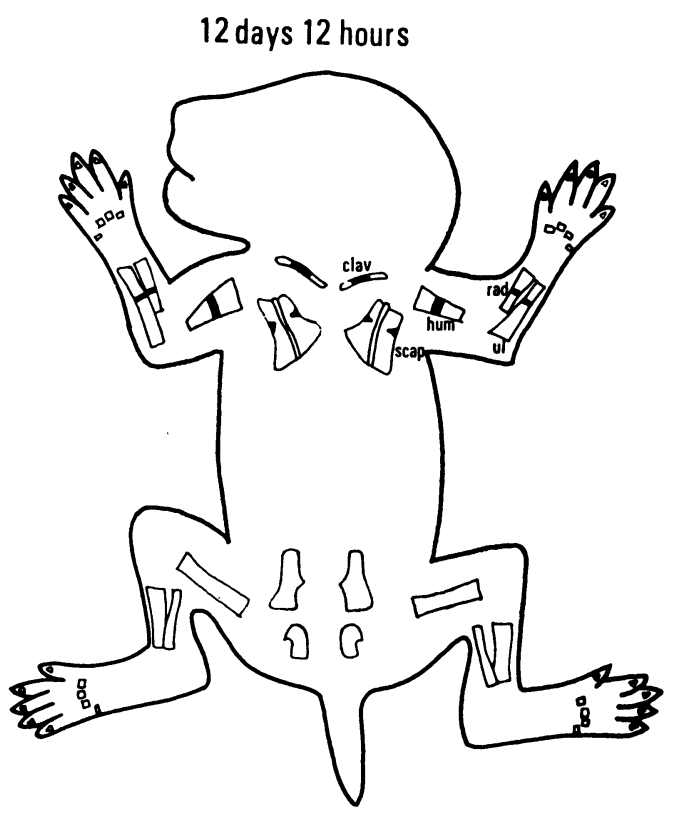

14 days 5 hours

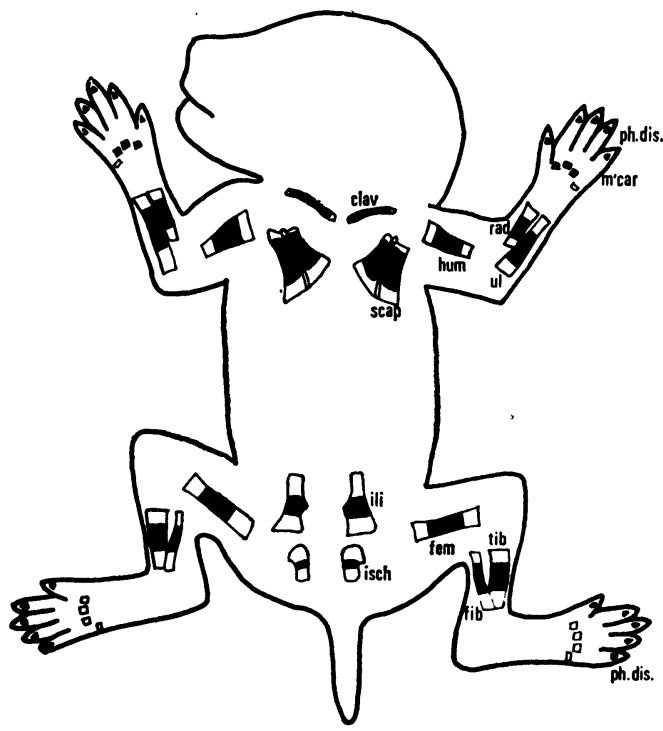

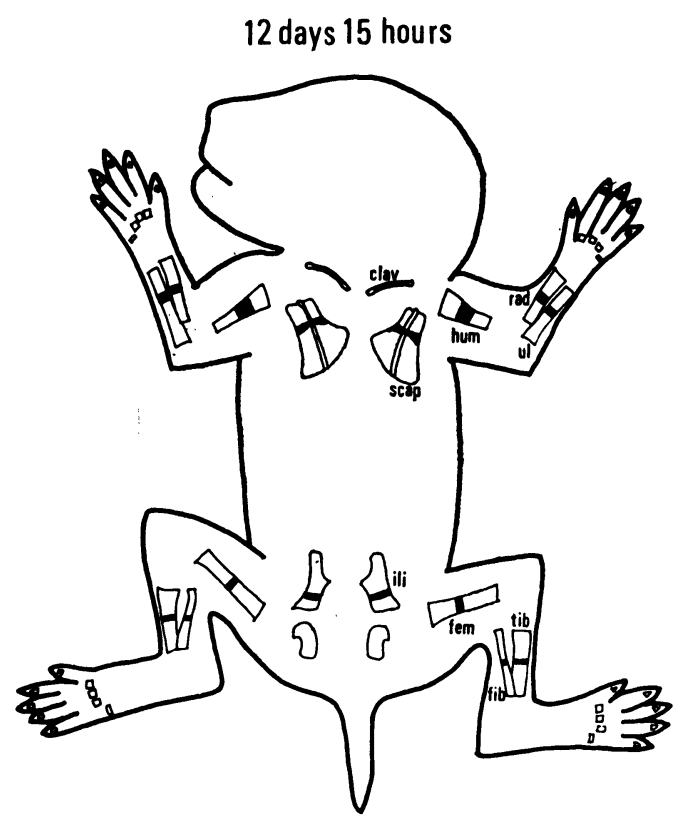

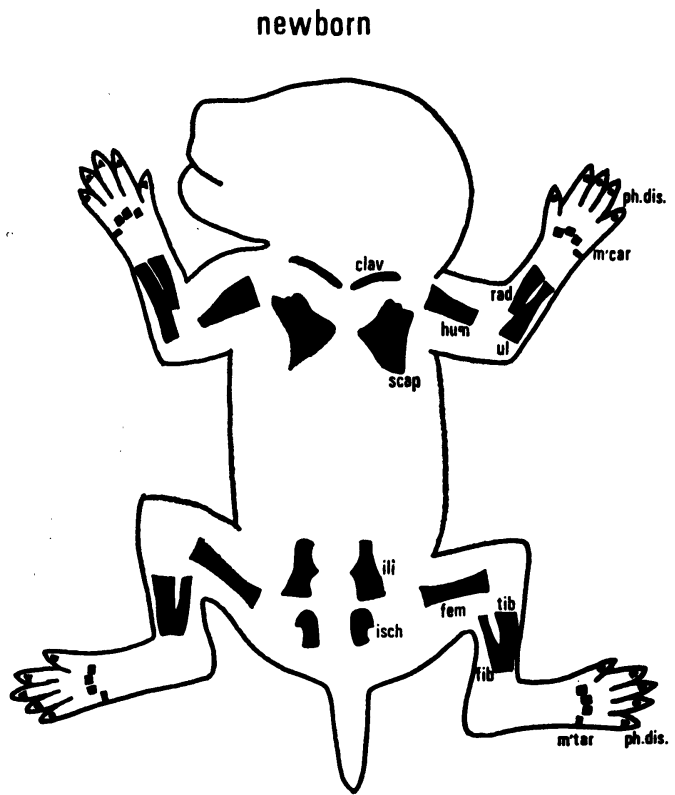

Explanation of the abbreviations: fem, femur; fib, fibula; hum, humerus; ili, ilium; isch, ischium; m'car, metacarpus; m'tar, metatarsus; ph. dis, distal phalange; rad, radius; scap, scapula; tib, tibia; ul, ulna. Refer to Fig. 1 for further explanations. 
ters of the femur, the tibia and the fibula were observed for the first time. The femur is developed to about $3.0 \mathrm{~mm}$ in length at birth. The shaft of the fibula is more slender than that of the tibia. At birth, both of them are

\section{$2.8 \mathrm{~mm}$ in length.}

In the distal five phalanges of the manus and the pes, the ossification centers appear at 13 days and 23 hours. At 14 days and 5 hours, the second, third and fourth metacarpi

Fig. 3. Average ossification in the skull.
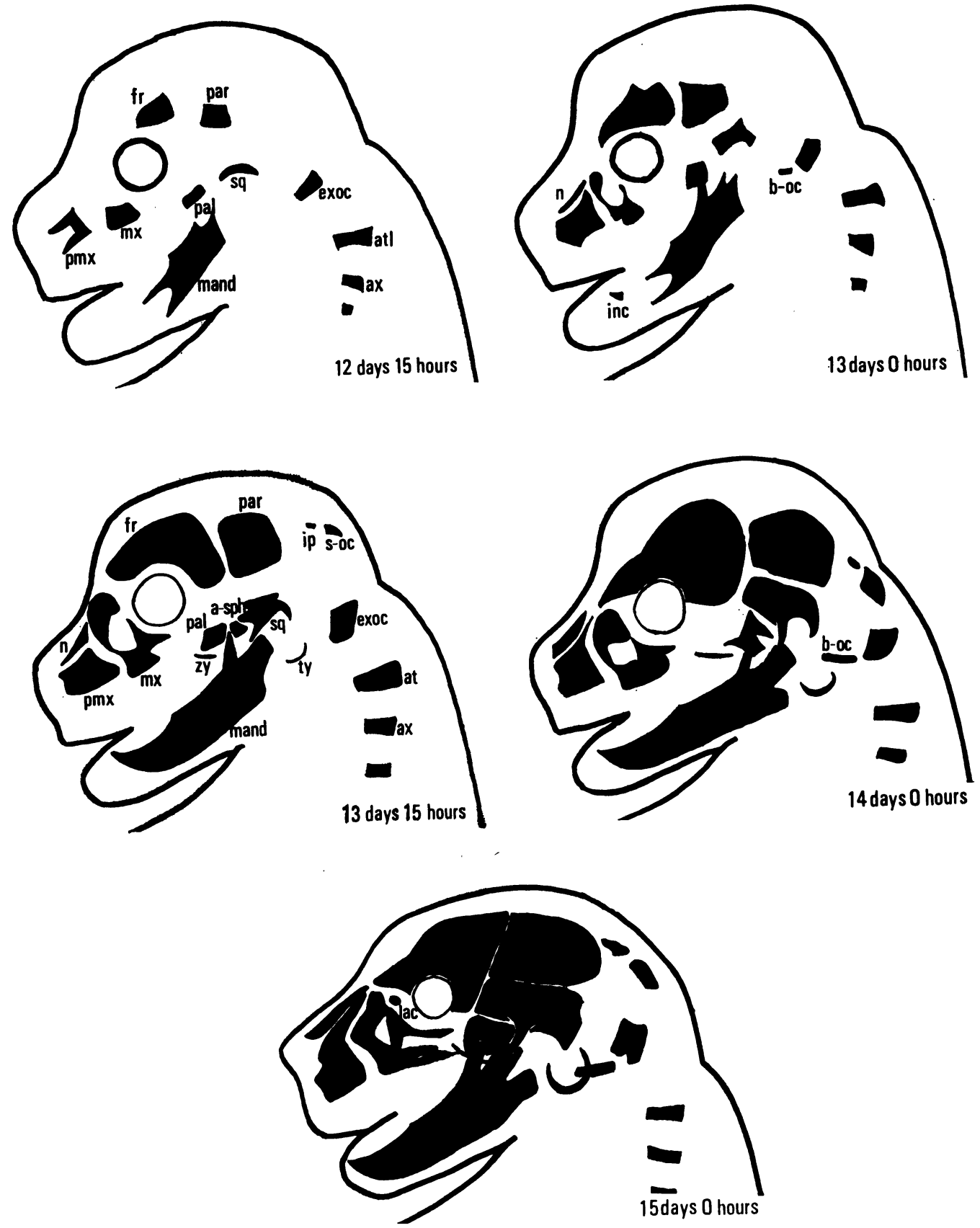

Explanation of the abbreviations: a-sph, alisphenoid; tym, tympanic ring; b-hy, basihyal; b-oc, basioccipital; b-sph, basisphenoid; exoc, exoccipital zy, zygomatic; $\mathrm{mx}$, maxilla; o-sph, orbitosphenoid; pal, palatine; sq, squamosal; vom, vomer. 
begin to ossify, preceding the ossification of the metatarsus which begins a little later. By the time of birth, the fifth metacarpus and metatarsus begin to ossify, and no other ossification centers appear at all.

4. The Skull. Table 5 shows the time and order of the appearance of ossification centers in the bones of the skull. Before the time of birth, all the bones except the ethmoid begin to ossify.

The first indicacion of ossification in the skull is found in the mandible at 12 days.

Fig. 4. Average ossification in the skull.
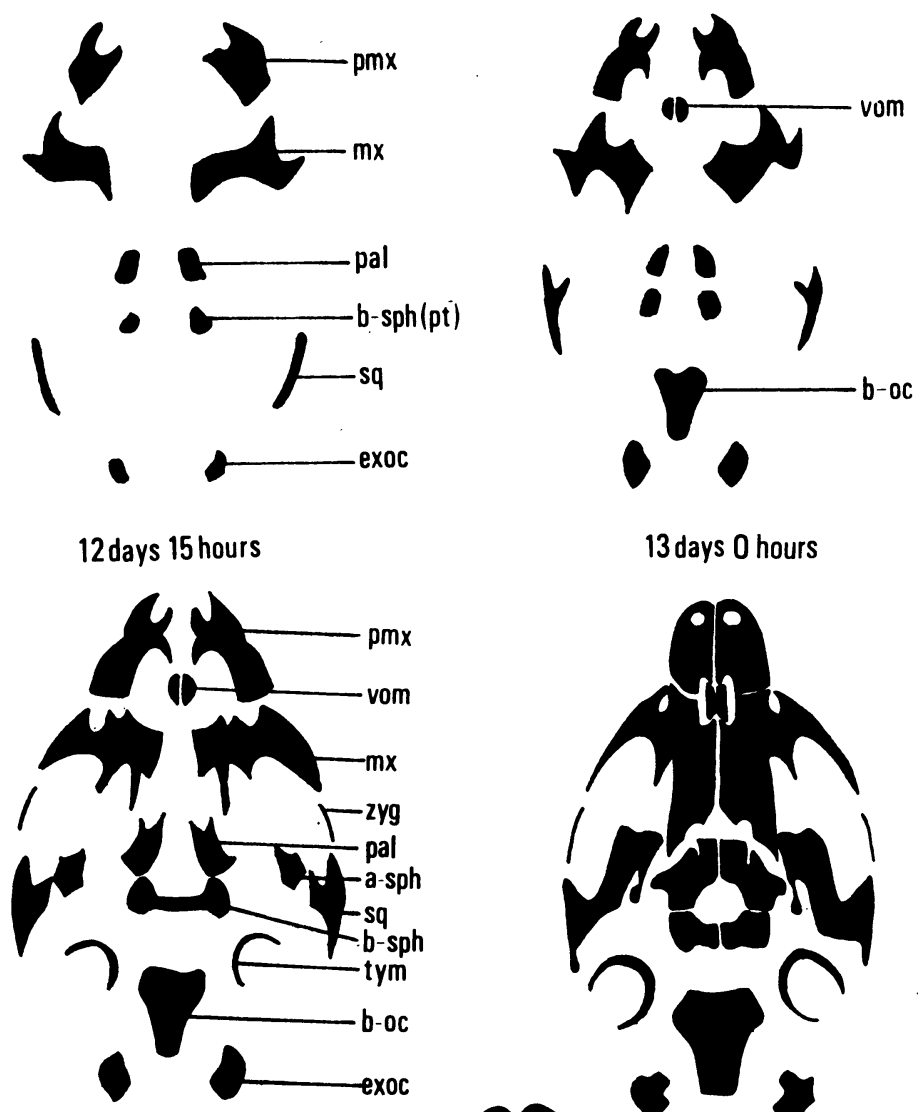

13 days 0 hours
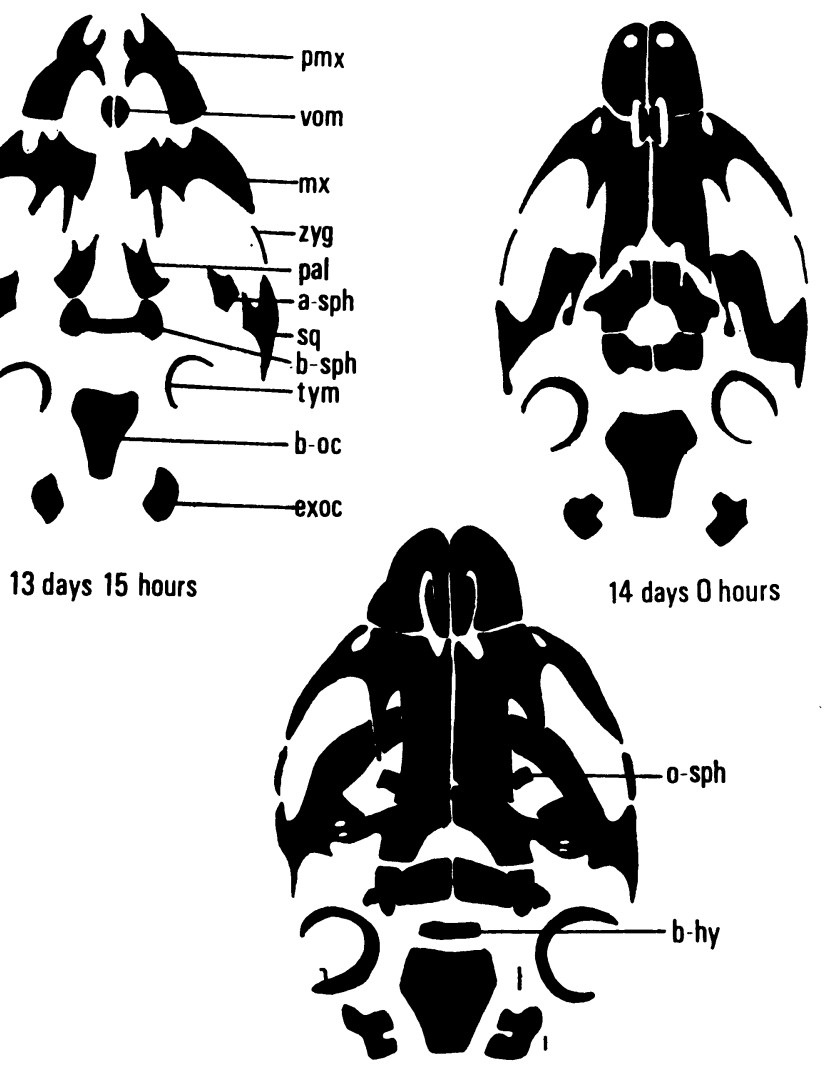

15 days 0 hours

The mandible is removed. Explanation of the abbreviations is given in Fig. 3. 
At 12 days and 12 hours, the maxilla and the premaxilla begin to ossify. In a few specimens, the former seems to be ossified earlier than the latter. At 12 days and 15 hours, the exoccipital, the basisphenoid, the pariental, the frontal, the squamosal, and the palatine begin to ossify approximately at the same time. At 13 days, ossification centers of the basioccipital, the nasal and the vomer appear.

The appearance of the center in the vomer seemed to be delayed in a few specimens. The centers of the alisphenoid and the supraoccipital begin to appear at 13 days and 3 hours.

Fig. 5 Comparison of the rate and order of appearance of the ossification centers appearing in the rat, the mouse, and the hamster during the gestation period.

1. The skull

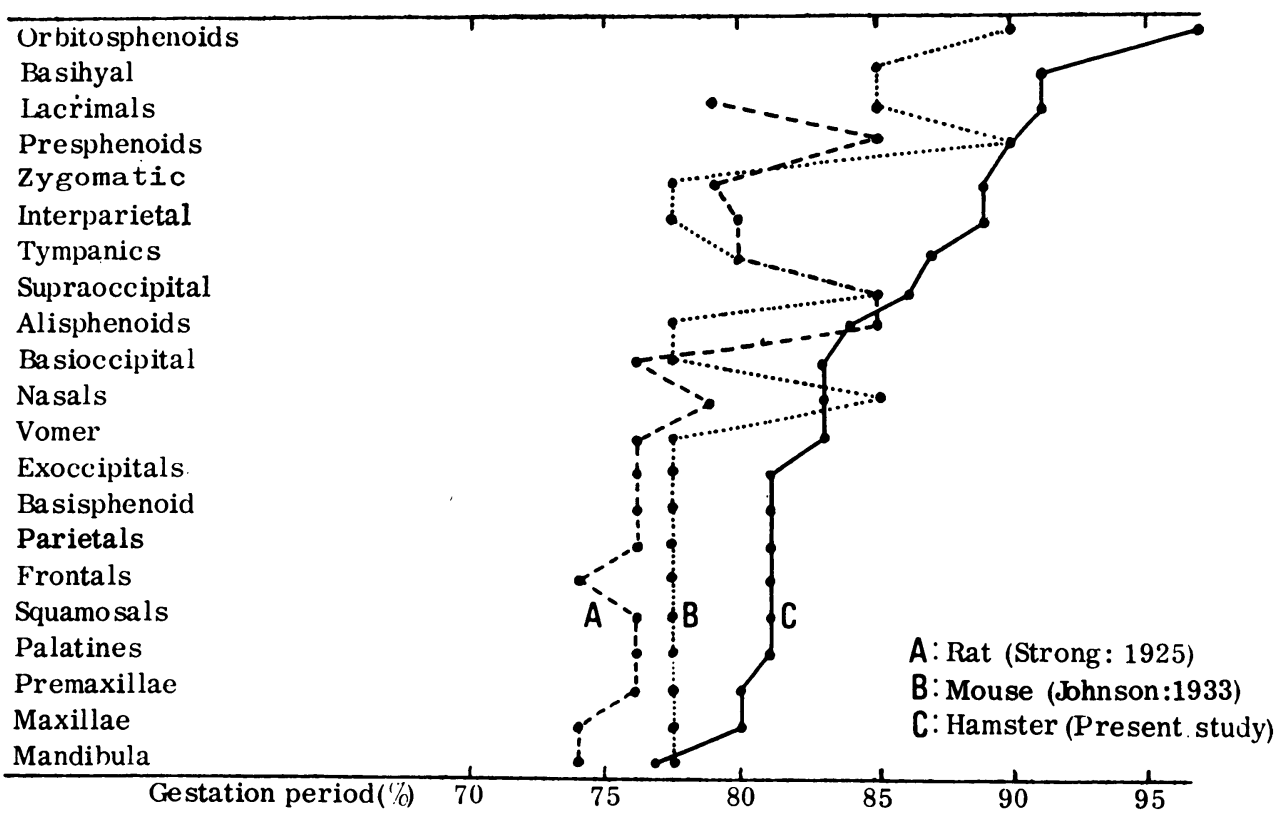

2. The vertebrae and the appendages

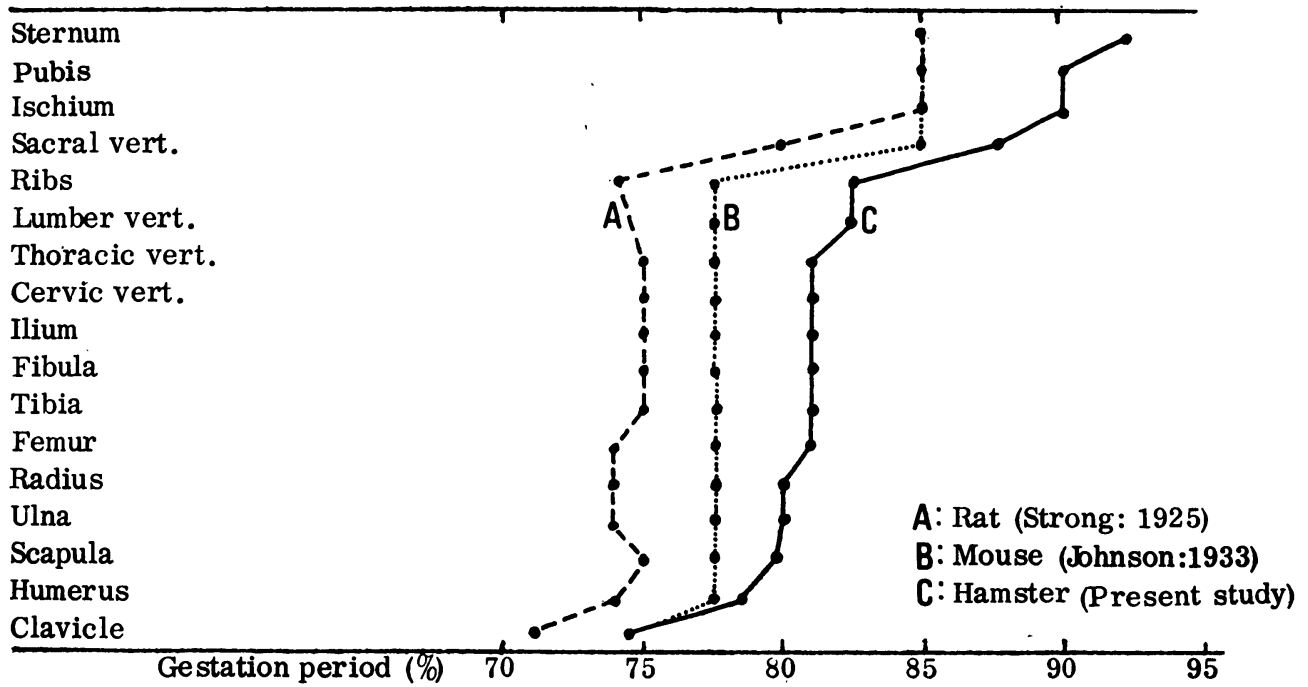


At 13 days and 15 hours, the tympanic, the interparietal and the zygomatic begin to ossify. The tympanic ossifies a little earlier than the others. The presphenoid ossifies at 14 days and 5 hours, and the basihyal and the lacrimal at 14 days and 15 hours. The ossification of the orbitosphenoid, which is the last of all the skull bones to ossify before birth, begins at 15 days. Fig. 3 and fig. 4 show the conditions of ossification at five different prenatal stages.

\section{Discussion}

Fig. 5 shows the rate and order of appearance of ossification centers in the rat [13], the mouse [8] and the golden hamster (present study). The gestation periods of these animals are 22.8 days for the rat, 20 days for the mouse, and 15.6 days for the hamster [9]. Gestation time of appearance of each ossification center was illustrated as a percent of the total gestation period in each animal. It is apparent from fig. 5 that in the hamster the ossification in the vertebrae, the appendages and the skull begins at a relatively later stage of gestation than that in the mouse and the rat as a result of the shorter gestation period in this animal. This is in accord with the view of Bruce [4] who studied the time and order of appearance of ossification centers in the rabbit skull, and compared the data with those of the man, the rat and the mouse. $\mathrm{He}$ concluded that the longer the gestation period, the earlier the relative stage of gestation when ossification centers appear, and that the animal of a shorter gestation period would be born with relatively immature skeletons.

As shown in fig. 5, in the vertebrae and the appendages, the appearance of each ossification center is almost in the same order among these three animals. In the skull, however, the order of ossification is not re- gular in the nasal, the alisphenoid, the zygomaticum, the interparietal and the tympanic regions. Beatty et al. [2] made a study concerning the appearance of ossification centers in the hamster, in which materials were obtained during intervals of one day. The order of ossification appears to be quite indefinite. The time of appearance of ossification centers of each skeleton in our data is roughly 10 to 24 hours earlier than that of Beatty et al.

The body weight of the fetus of the hamster increases rapidly from the 13th day in gestation [9]. Ossification begins a day before the rapid increase of the body weight, which shows that the formation of the skeleton prepares for the rapid body growth. The newborn hamster represents a relatively younger skeletal age than the rat and the mouse especially in the manus and pes. In the rat and the mouse, more centers are present at birth than the hamster in the manus and pes $[8,13]$. The prenatal growth of the hamster is indeed "explosive", but its skeletal system is still immature.

\section{References}

[1] Arsdel, W.C. and H.H. Hillemann (1951) The ossification of the middle and internal ear of the golden hamster (Cricetus auratus). Anat. Rec. 109: 673-689.

[2] Beatty, M.D. and H.H. Hillemann (1950) Osteogenesis in the golden hamster. J. Mammal. 31: 121-134.

[3] Beyerlein, L., H. H. Hillemann and W.C. Arsdel (1951) Ossification and calcification from postnatal day eight to the adult condition in the golden hamster. Anat. Rec. 111: $49-65$.

[4] Bruce, J. A. (1941) Time and order of appearance of ossification centers and their development in the skull of the rabbit. Am. J. Anat. 68: 41-67.

[5] Dawson, A.B. (1926) A note on staining of the skeleton of cleared specimens in alizarin red S. Stain Techn. 1: 123-124.

[6] Friant, M. (1958a) Sur les premiers stades d'ossification du cartilage de Meckel. Acta Anat. 32: 100-114. 
[7] Friant, M. (1958b) Sur l'evolution du cartilage de Meckel. Acta Anat. 34 : 293-297.

[8] Johnson, M.L. (1933) The time and order of appearance of ossification centers in the albino mouse. Am J. Anat. 52 : 241-271.

[9] Lee, C.S. (1973) Normal growth of the hamster. Thesis, University of Tokyo.

[10] Rajtova, V. (1972) Über die Morphogenesis des Chondrocraniums beim Goldhamster (Mesocricetus auratus Wrth). Anat. Anz. 130: 207-221.

[11] Robinson, P.F. (1968) Physiology of repro- duction. The golden Hamster. It's Biology and Use in Medical Research (edit. by Hoffman, R.A., Robinson, P.F. and Magalhaes, H.), 119-138, Iowa State Univ. Press, Ames.

[12] Schumacher, G.H., E. Wolff and G. Schultz (1963) Wachstumsallometrien am skeleet des Goldhamsters (Mesocricetus auratus Wrth). I. Schädel. Morph. Jahrb. 105: 205-230.

[13] Strong, R. M. (1925) The order, time and rate of ossification of the albino rat. Am. J. Anat., 36: 313-355.

\title{
ハムスターの骨化点出現時期と順序
}

\author{
金沢英作 ${ }^{*}$ 望月公子** \\ * 北里大学医学部解剖学教室 \\ $* *$ 東京大学農学部家畜解剖学教室
}

\footnotetext{
ゴールデンハムスター（クリーム系）の正常発育階 程を求める目的で，411 例の胎児を用い, 全身骨格の 骨化点出現時期と順序を調べた。

1. 最初の骨化点は11日15時間に鎖骨に現われ，以 後順次各骨に骨化点が出現するが，その順序は頭蓋骨 の一部を除いてラット，マウスのそれらと一致する点 が多かった。
}

2. 骨化点の出現時期は鎖骨など非常に早いものを 除いて，妊娠期間を 100 とした場合のほぼ80\%からは
じまっている。これはラットの71.5\%，マウスの75\% よりる出現時期がさらに妊娠末期に片寄っていること を意味し，一般に妊娠期間の長いものほど骨格の骨化 は妊娠の比較的早期に行われるといら説を裏づけるも のである。

3. 八ムスター胎児の体重は妊娠13日から急激に増 加するが，骨化は12日前後からはじまる。

4. 出生時の骨格はラット, マウスよりやや未熟な 状態にあると考えられる結果を得た。 